\title{
Litter stock and quality in Eucalyptus grandis in Northern Rio de Janeiro State, Brazil
}

\author{
Gláucio de Mello Cunha ${ }^{1}$ (1) 0000-0002-7842-014X \\ Gilmar Santos Costa ${ }^{2}$ (D) 0000-0001-8534-0028 \\ Antonio Carlos Gama-Rodrigues ${ }^{3}$ (1) 0000-0003-2070-7743
}

\begin{abstract}
Litter decomposition restores part of the elements absorbed by the plant back into the soil, acting as a regulator of the biogeochemical cycling of nutrients. This study aimed to evaluate the litter quantity and quality of Eucalyptus grandis in Northern Fluminense region, RJ. Three rotational sequences were studied, the first after 8 years (FR8), the second after 1.5 years (SR2), and a 5year old regrowth (R5). Leaf litter was divided into whole leaves (WL), fragmented pieces (FP), twigs/branches (TB), reproductive structures (RS) and bark (B). The total litter in FR8 was 9.56 $\mathrm{Mg} \mathrm{ha}^{-1}$, in SR2, 13.85, and in R5, $22.97 \mathrm{Mg} \mathrm{ha}^{-1}$, corresponding to 83, 163 and $75 \mathrm{~kg} \mathrm{ha}^{-1}$ of N, respectively. FP represented $38 \%, 48 \%$ and $55 \%$ of $\mathrm{N}$, respectively, in SR2, R5 and FR8. The WL and FP fractions have high recycling potential of organic matter and nutrients due to their lower $\mathrm{C} / \mathrm{N}$ and Lig/ $\mathrm{N}$ quality index values.
\end{abstract}

Keywords: C:N ratio, eucalyptus, lignin, nutrient cycling.

\section{INTRODUCTION AND OBJECTIVE}

Eucalyptus cultivation in Brazil occurs in very diverse climate, soil and topography conditions (Gonçalves et al., 2013). There have been plantations in the form of windbreakers, subsistence crops, agroforestry systems, small-scale commercial crops without fertilization management and predominantly high-tech commercial crops. This is due to the great adaptation versatility of the different eucalyptus species and to the ability of eucalyptus producers in Brazil to take advantage of these capacities of the plant. Common sense among small-scale farmers is that the eucalyptus "grows well anywhere", so usually they plant it in marginal areas on the property. Despite the productive capacity of this plant, crop management is essential so that its production reverts to positive income from the economic point of view.

In the State of Rio de Janeiro, the eucalyptus crops are cultivated mostly in small areas. The approximately 18,000 ha occupied by this crop are distributed in 998 cultivated areas (Amorim et al., 2012), indicating an average of 18 ha per area.
In the north of the state, small-scale eucalyptus plantations are relatively common, even though their detection was not very significant in a survey conducted by Amorim et al. (2012), since the minimum identifiable area used was 4 ha. Eucalyptus plantations in this region are generally means of species diversification in a scenario of sugar cane monoculture and pasture. Wood production aims to meet the great demand for firewood by the ceramic and construction industries. However, much of this demand is met by wood produced in neighboring states, especially ES.

The nutrient requirement for forest stand development differs among species, productivity levels and plant ages (Turner \& Lambert, 2008). In short rotation plantings with regrowth management there is a need for replanting fertilization to attain production sustainability (Gatto et al., 2014). Despite the need for fertilization so that the subsequent productivity is no affected, some of the nutrients absorbed by the stands are provided by the decomposing residues added to the soil as litter (Rocha et al., 2016;

\footnotetext{
${ }^{1}$ Universidade Federal do Espírito Santo (UFES), Alegre, ES, Brasil

${ }^{2}$ Instituto Federal de Educação, Ciência e Tecnologia Fluminense (IFF), Campos dos Goytacazes, RJ, Brasil

${ }^{3}$ Universidade Estadual do Norte Fluminense Darcy Ribeiro (UENF), Campos dos Goytacazes, RJ, Brasil
} 
Silva et al., 2013). Thus, the contribution of litter to plant nutrition most likely becomes more important under conditions of inadequate fertilization management.

Litter formation happens by the natural fall of organic materials that constitute plant structures, e.g., leaves, branches, bark and reproductive structures. This residue stock on the soil plays an important role in regulating nutrient cycling and maintaining soil fertility in forest systems (Laclau et al., 2010). On the other hand, the litter quality depends mainly on the chemical quality of the compounds present in these materials (Prescott, 2010). Another aspect in the transference of nutrients from the litter to the plant or soil is the decomposition process, controlled by several factors, including abiotic ones (Makkonen et al., 2012; Powers et al., 2009; Souza et al., 2016; Waring, 2012), which determine transfer rates.

Plants produce a wide variety of secondary compounds that contain phenolic groups, including lignin, flavonoids, isoflavonoids and tannins (Mazid et al., 2011). These compounds can be divided into low molecular weight compounds, oligomers and high molecular weight polymers (Hättenschwiler \& Vitousek, 2000). They act as defense barriers for the plants against predators and pathogens, based on the toxic or repellent nature of herbivores and microorganisms, acting as well as a defense against abiotic stress (Mazid et al., 2011). Polyphenols are known to affect litter quality, sometimes with greater effects than $\mathrm{N}$ and lignin on the decomposition rate. On the other hand, phenolic compounds also affect directly the composition and activity of decomposing organisms, influencing the decomposition rate and the nutrient cycling (Hättenschwiler \& Vitousek, 2000). In this sense, recognizing the proportion of these secondary compounds in plant residues may help to understand the nutrient cycling dynamics in several ecosystems. Thus, under the same edaphoclimatic conditions, the quality of the substrate in forest systems becomes the main regulating variable of the decomposition process.
The objective of the present study was to evaluate the litter amount and quality in a Eucalyptus grandis stand, at different rotation ages, in the North Fluminense region, RJ, Brazil.

\section{MATERIALS AND METHODS}

The studied area is located in the municipality of São Francisco do Itabapoana, in the State of Rio de Janeiro, Brazil. The average annual temperature during the experimental period was $22.7^{\circ} \mathrm{C}$, with a minimum of $19.5^{\circ} \mathrm{C}$ and maximum of $26.7^{\circ} \mathrm{C}$. The average annual rainfall was $848 \mathrm{~mm}$, with $54 \%$ of it from October to December. The soil of the area was classified as Yellow Argisol, which presents low chemical fertility (Table 1).

The evaluated plots of Eucalyptus grandis had different planting ages and managements, being classified as follows: FR8, first rotation, at 8 years old; SR2, second rotation, regrowth at 1.5 years old; and $\mathrm{R} 5$, second rotation, regrowth at 5 years old, according to the characterization described by Cunha et al. (2005). The eucalyptus harvest in the area was done by removing trunks with bark, and leaving the harvest residue (leaves and branches) on the soil.

Two plots with dimensions of $20 \times 25 \mathrm{~m}$ each were randomly demarcated for the collection of the accumulated litter. A wooden square of $0.50 \times 0.50 \mathrm{~m}$, which was randomly thrown four times in each area, was used to do so. The organic material deposited on the soil contained in these $0.25 \mathrm{~m}^{2}$ areas was collected in order to quantify the litter. This procedure was performed once at the end of the wet season (February), and once at the end of the dry season (August).

The material collected to quantify the litter was separated into the following components: freshly fallen whole leaves (WL); fragmented pieces (fragmented leaves with dark staining) (FP); twigs/branches (TB); reproductive structures (RS); and bark (B). Minor and non-recognizable fragments were designated (RI). The different litter components were oven dried at $65^{\circ} \mathrm{C}$ to constant weight.

Table 1. Chemical characteristics of the soil at the depth of $0-20 \mathrm{~cm}$ in an E. grandis stand in Northern Rio de Janeiro, Brazil (Costa et al., 2005).

\begin{tabular}{|c|c|c|c|c|c|c|}
\hline & pH & $\mathrm{Ca}$ & Mg & $\mathbf{A l}$ & K & $\mathbf{P}$ \\
\hline & & \multicolumn{3}{|c|}{$\mathbf{m m o l}_{\mathrm{c}} \mathbf{d m}^{-3}$} & \multicolumn{2}{|c|}{${ }^{\mathrm{m}} \mathrm{mg} \mathrm{dm}^{-3}$} \\
\hline SR2 & 4.82 & 7.3 & 2.9 & 3.6 & 0.6 & 2.82 \\
\hline R5 & 4.89 & 6.2 & 3.5 & 3.6 & 0.6 & 2.72 \\
\hline FR8 & 4.88 & 6.3 & 3.2 & 4.5 & 0.9 & 3.08 \\
\hline
\end{tabular}

SR2: E. grandis regrowth at 1,5 years; R5: E. grandis regrowth at 5 years; FR8: 8-year-old E. grandis plantation. 
For the chemical analysis, the samples obtained in each lot were grouped by litter component in composite samples, one for each time of the year. The plant material was grated and then subjected to a chemical analysis. The $\mathrm{C}$ and total soluble polyphenols were determined based on the procedure described by Anderson \& Ingram (1996), while lignin and cellulose were determined by the acid detergent fiber method (Anderson \& Ingram, 1996; Van Soest \& Wine, 1968). N was analyzed based on the method recommended by Bremmer \& Mulvaney (1982). P, K, Ca and Mg were determined after nitric-perchloric digestion, according to the recommendations of Bataglia et al. (1983).

The total amount of $\mathrm{C}$, cellulose, lignin, polyphenols, $\mathrm{N}, \mathrm{P}, \mathrm{K}, \mathrm{Ca}$ and $\mathrm{Mg}$ was obtained by multiplying the concentration of each litter component by its mass. The sum of the results corresponded to the total accumulated in each forest cover.

A 95\% confidence interval was estimated for the means of the studied variables, associated to the precision expressed by the standard error and to the experimental variability measured in the coefficient of variation.

\section{RESULTS AND DISCUSSION}

The average amount of accumulated litter, including non-recognizable residues (RI), was $13.85 \mathrm{Mg} \mathrm{ha}^{-1}$ in SR2, $22.97 \mathrm{Mg} \mathrm{ha}^{-1}$ in R5 and 9.56 $\mathrm{Mg} \mathrm{ha}^{-1}$ in FR8. Except for the RI residue, litter accumulation ranged from $8.7 \pm 0.8$ to $20.8 \pm 2.7 \mathrm{Mg} \mathrm{ha}^{-1}$ ha-1 (Figure 1a). SR2 and FR8 values were close, both being surpassed by R5, which had approximately the double amount of litter. The most pronounced seasonal effect was observed in R5, with a higher amount of material accumulated in the dry season. Turner \& Lambert (2008) reported the values of 5.33 and $11.80 \mathrm{Mg} \mathrm{ha}^{-1}$ of accumulated litter, on a first-rotation planting of E. grandis, at the ages of 2 and 5 years, respectively. In a commercial planting of E. urophylla $\times$ E. globulus hybrid, Schumacher et al. (2013) found 13.7 $\mathrm{Mg} \mathrm{ha}^{-1}$ of stored litter. The relatively high litter values in SR2 are due to the presence of crop residue fragments (as well as to the residues of management thinnings), since the litter contribution rate of crops at younger ages is generally lower (Cunha et al., 2005; Turner \& Lambert, 2008). The high amount of accumulated litter in R5 also reflects the presence of harvest residues of the previous cycle, mainly branches, added to the residues produced by the second rotation (litter and thinning residues).

Analyzing the litter components, it is observed that the average amounts varied: from 0.4 to $1.4 \mathrm{Mg} \mathrm{ha}^{-1}$ for whole leaves (WL) (Figure 1b); from 2.7 to $6.9 \mathrm{Mg} \mathrm{ha}^{-1}$ for fragmented pieces (FP) (Figure 1c); from 4.8 to $9.3 \mathrm{Mg} \mathrm{ha}^{-1}$ for twigs/branches (TB) (Figure 1d); from 0.16 to $1.77 \mathrm{Mg} \mathrm{ha}^{-1}$ for bark (B) (Figure 1e); and from 0.08 to $1.41 \mathrm{Mg} \mathrm{ha}^{-1}$ for reproductive structures (RS) (Figure 1f). In relative terms, the WL component corresponded to $11.7 \%$ of FR8 litter, a higher value than those of R5 (6.6\%) and SR2 (4.3\%). Cunha Neto et al. (2013) found that the leaf ratio in the litter, without distinction between whole leaves and fragmented leaves, reached $44 \%$ in E. grandis $\times$ E. urophylla hybrid at 4.5 years old.

The twig/branch fraction represented a high proportion of the litter residue ( 44.8 to $54.4 \%$ ) (Figure 1). In absolute terms, it can be observed that the branches in R5 represented higher biomass values when compared to those of other ages, reaching $9.3 \mathrm{Mg} \mathrm{ha}^{-1}$. The great contribution of branches in the litter biomass is due to the harvest residues, as well as to the addition of stalks of the sprouts cut during the coppice management. The annual fall of branches noted by Cunha et al. (2005) corroborated this understanding, since the litterfall material collected in these same plots was only $1.31 \mathrm{Mg} \mathrm{ha}^{-1}$ in FR8, $0.67 \mathrm{Mg} \mathrm{ha}^{-1}$ in SR2 and $1.35 \mathrm{Mg} \mathrm{ha}^{-1}$ in R5.

The fragmented pieces fraction, which includes materials of reduced size, with a predominance of leaves in several fragmentation stages, was more representative than the whole leaves fraction in the litter composition. Notably, the whole leaves indicate recent deposition while the fragmented pieces fraction integrates the litter components in different decomposition stages. The amount of FP was 5 times higher than that of WL in R5, while it was only 1.7 times the amount of WL in FR8. Thus, the residue fragmentation index increases in the second rotation age. In this context, understanding the fragmentation as one of the decomposition processes (Swift et al., 1979) could indicate that R5 would be at a later stage of residue decomposition than SR2.

The mean $\mathrm{N}$ concentration in the litter was $7.0 \mathrm{~g} \mathrm{~kg}^{-1}$ in SR2, in FR8 it was $7.7 \mathrm{~g} \mathrm{~kg}^{-1}$ and in R5 it was $7.5 \mathrm{~g} \mathrm{~kg}^{-1}$ (Table 2). The variation of nutrient concentrations was similar in the different litter components, except in the twigs and bark, which presented much lower $\mathrm{N}$ and $\mathrm{P}$ concentrations. In these same areas, Cunha et al. (2005) found mean values of $10.74 \mathrm{~g} \mathrm{~kg}^{-1}$ in SR2, $12.00 \mathrm{~g} \mathrm{~kg}^{-1}$ in R5 and $10.04 \mathrm{~g} \mathrm{~kg}^{-1}$ in FR8, for the nutrient concentrations in the leaf litter, including intact leaves and leaves in several stages of decomposition. Mean $\mathrm{P}$ and Ca values were close to those presented by intact leaves in the different ages, while the values for $\mathrm{K}$ and $\mathrm{Mg}$ reported herein were higher. 

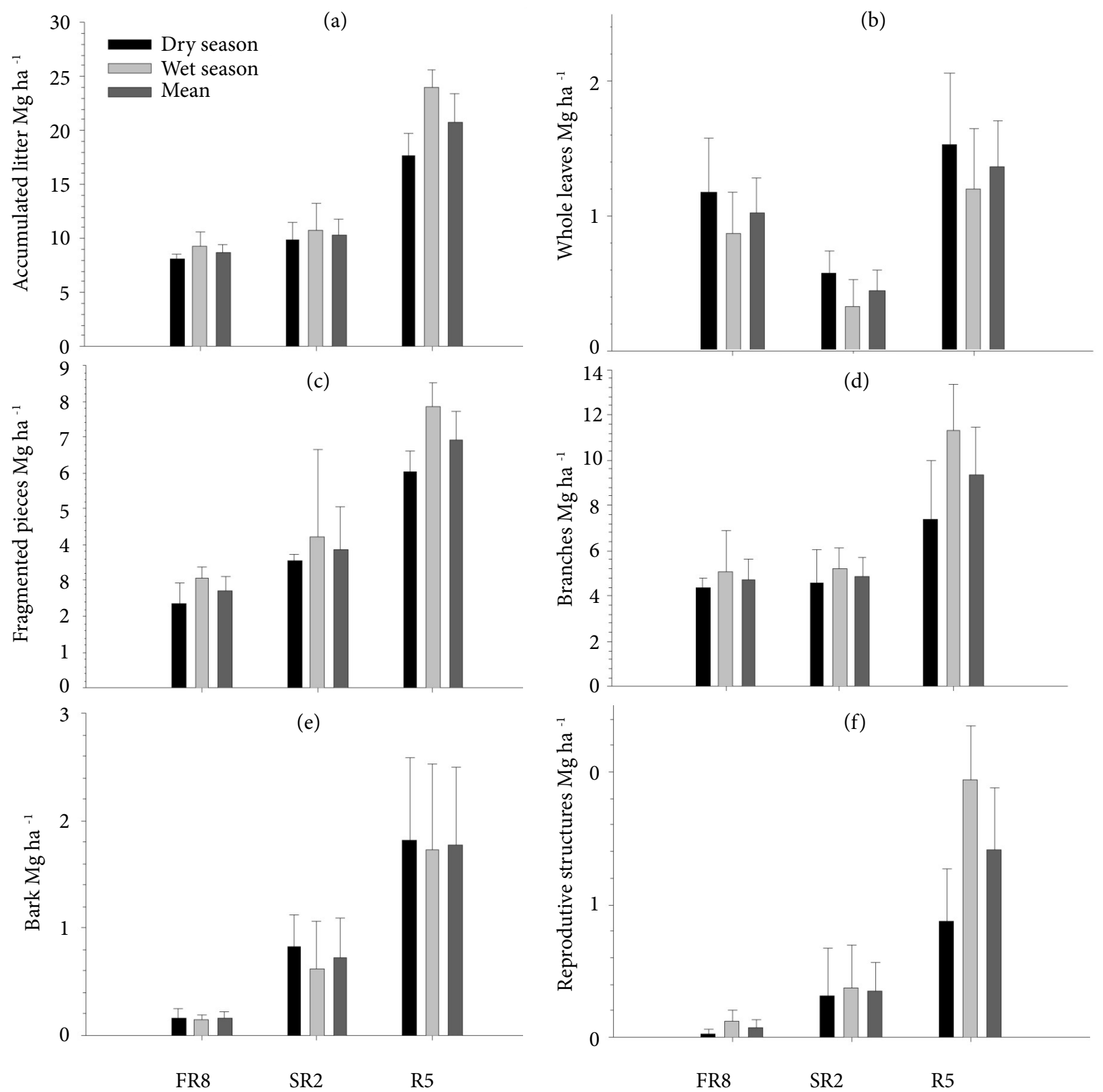

Figure 1. Total amount of litter and its accumulated components in an E. grandis stand in Northern Rio de Janeiro, Brazil.

FR8: first rotation of an 8-year-old stand; SR2: second rotation of a 1.5-year-old stand; R5: second rotation of a 5-year-old stand. Bars inserted in the columns represent the confidence interval of $95 \%(p=0.05)$.

Table 2. Nutrient Concentration $\left(\mathrm{g} \mathrm{kg}^{-1}\right)$ in litter fractions (LF) of E. grandis stands in the first and second rotations, in Northern Rio de Janeiro, Brazil.

\begin{tabular}{|c|c|c|c|c|c|c|c|c|c|c|c|c|c|c|c|}
\hline \multirow[t]{2}{*}{ LF } & \multicolumn{5}{|c|}{ SR2 } & \multicolumn{5}{|c|}{ R5 } & \multicolumn{5}{|c|}{ FR8 } \\
\hline & $\mathbf{N}$ & $\mathbf{P}$ & K & $\mathrm{Ca}$ & $\mathrm{Mg}$ & $\mathbf{N}$ & $\mathbf{P}$ & $\mathbf{K}$ & $\mathrm{Ca}$ & $\mathbf{M g}$ & $\mathbf{N}$ & $\mathbf{P}$ & K & $\mathrm{Ca}$ & Mg \\
\hline WL & 9.3 & 0.31 & 1.2 & 10.4 & 2.2 & 12.6 & 0.39 & 1.0 & 9.3 & 2.2 & 9.5 & 0.28 & 0.9 & 11.3 & 2.4 \\
\hline TB & 4.3 & 0.15 & 0.4 & 12.9 & 1.8 & 4.3 & 0.14 & 0.4 & 5.0 & 1.2 & 4.6 & 0.13 & 0.3 & 7.4 & 1.1 \\
\hline $\mathrm{FP}$ & 10.8 & 0.37 & 0.5 & 11.5 & 1.9 & 11.4 & 0.42 & 0.7 & 11.4 & 2.0 & 12.1 & 0.33 & 0.5 & 12.7 & 1.8 \\
\hline RS & 10.0 & 0.41 & 0.6 & 12.6 & 2.1 & 9.0 & 0.4 & 0.1 & 8.8 & 2.5 & 9.0 & 0.34 & 0.7 & 10.9 & 1.9 \\
\hline B & 4.6 & 0.14 & 0.3 & 6.9 & 1.2 & 3.9 & 0.13 & 0.4 & 5.5 & 1.5 & 4.2 & 0.15 & 0.4 & 7.4 & 1.3 \\
\hline
\end{tabular}

WL: whole leaves; TB: twigs/branches; FP: fragmented pieces; RS: reproductive structures; B: bark; SR2: second rotation after 1.5 years; R5: second rotation after 5 years; FR8: first rotation. 
The amount of $\mathrm{N}$ stored in the litter was $75 \mathrm{~kg} \mathrm{ha}^{-1}$, $163 \mathrm{~kg} \mathrm{ha}^{-1}$ and $83 \mathrm{~kg} \mathrm{ha}^{-1}$, respectively, for SR2, R5 and FR8. The fraction that contributed the most to these results was FP, representing $38 \%, 48 \%$ and $55 \%$ of stored $\mathrm{N}$, respectively (Figure 2a). In a E. urophylla $\times$ E. globulus hybrid at 6 years old, Viera et al. (2013) found $103 \mathrm{~kg} \mathrm{ha}^{-1}$ of $\mathrm{N}$ in the litter, but after 9 years from planting, $\mathrm{N}$ accumulation increased to $127 \mathrm{~kg} \mathrm{ha}^{-1}$. A N accumulation of $68 \mathrm{~kg} \mathrm{ha}^{-1}$ was verified by Cunha Neto et al. (2013) in a Urograndis hybrid at 4.5 years after planting. Thus, the stock of $\mathrm{N}$ and other nutrients tends to grow with the increasing biomass stored on the soil, making up an important reserve for nutrient cycling. Keeping the crop residue in the study area was fundamental to increase the $\mathrm{N}$ stock on the soil. It is noteworthy that even nutrientpoor fractions such as branches contribute significantly to the final count of the stock when in large volume. The FP fraction represented proportionally higher stocks of $\mathrm{N}, \mathrm{P}, \mathrm{Ca}$ and $\mathrm{Mg}$, except in SR2, where $\mathrm{Ca}$ and $\mathrm{Mg}$ stocks were higher in the branch fraction (Figures $2 \mathrm{a}, 2 \mathrm{~b}, 2 \mathrm{~d}$ and $2 \mathrm{e}$ ).

The $\mathrm{C}$ concentration in litter components ranged from 406 to $479 \mathrm{~g} \mathrm{~kg}^{-1}$ (Table 3). The highest values occurred in the WL component in the three studied plots. An average concentration of $487.5 \mathrm{~g} \mathrm{~kg}^{-1} \mathrm{C}$ in Urograndis hybrid litter was found by Skorupa et al. (2015). In this study, the mean C
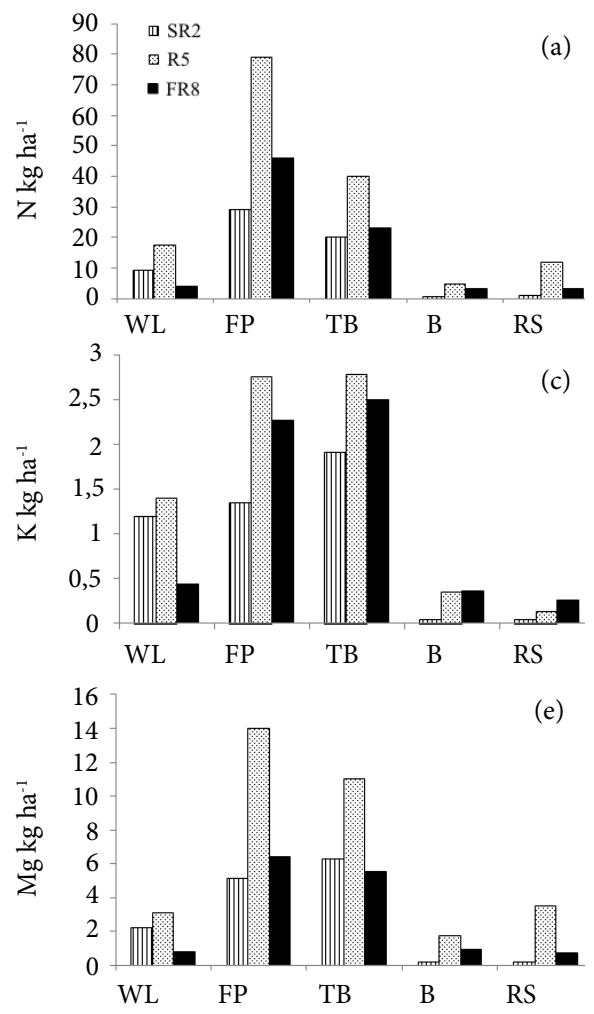

Figure 2. Nutrient content in E. grandis litter fractions in the first and second rotations, in Northern Rio de Janeiro, Brazil. FR8: first rotation of an 8-year-old stand; SR2: second rotation of a 1.5-year-old stand; R5: second rotation of a 5-year-old stand; WL: whole leaves; FP: fragmented pieces; TB: twigs/branches; B: bark; RS: reproductive structures. concentration in the litter was of $442.4( \pm 20.1) \mathrm{g} \mathrm{kg}^{-1}$ in SR2, $443.6( \pm 20.4) \mathrm{g} \mathrm{kg}^{-1}$ in R5 and $435.0( \pm 21.7) \mathrm{g} \mathrm{kg}^{-1}$ in FR8.

In ascending order $\mathrm{FP}<\mathrm{WL}<\mathrm{RS}<\mathrm{B}<\mathrm{TB}$ presented average values of cellulose between 166 and $309 \mathrm{~g} \mathrm{~kg}^{-1}$ (Table 3). The mean cellulose amount in SR2 litter was 211 $( \pm 66.5) \mathrm{g} \mathrm{kg}^{-1}$, while for in R5 it was $194.4( \pm 57.2) \mathrm{g} \mathrm{kg}^{-1}$, and in FR8 it was $286( \pm 40.9) \mathrm{g} \mathrm{kg}^{-1}$.

The lignin found in WL and FP varied little among the residues of the three studied plots. The mean lignin concentration was $205( \pm 11.4) \mathrm{g} \mathrm{kg}^{-1}$ and $270( \pm 12.6) \mathrm{g} \mathrm{kg}^{-1}$ in $\mathrm{WL}$ and FP, respectively. The average lignin concentration in branch fractions of all the plots was of $368( \pm 54.7) \mathrm{g} \mathrm{kg}^{-1}$, about $44 \%$ higher than the one found in WL and $27 \%$ higher than that in FP. The litter in SR2 was composed by an average of 275 ( \pm 70.2$) \mathrm{g} \mathrm{kg}^{-1}$ of lignin, while in R5 and FR8 the lignin means were $267( \pm 55.6) \mathrm{g} \mathrm{kg}^{-1}$ and $293( \pm 72.5) \mathrm{g} \mathrm{kg}^{-1}$, respectively (Table 3 ). Studies in eucalyptus stands in the Northern Fluminense region indicate lignin values ranging from 112 to $312 \mathrm{~g} \mathrm{~kg}^{-1}$ in Urograndis hybrids, depending on the cultivation age (Barreto et al., 2008). In turn, Skorupa et al. (2015), also studying the Urograndis hybrid and established in Vale do Rio Doce, MG, did not find significant differences in the lignin concentration as a function of the cultivation age, , obtaining a mean content of $328.3 \mathrm{~g} \mathrm{~kg}^{-1}$.
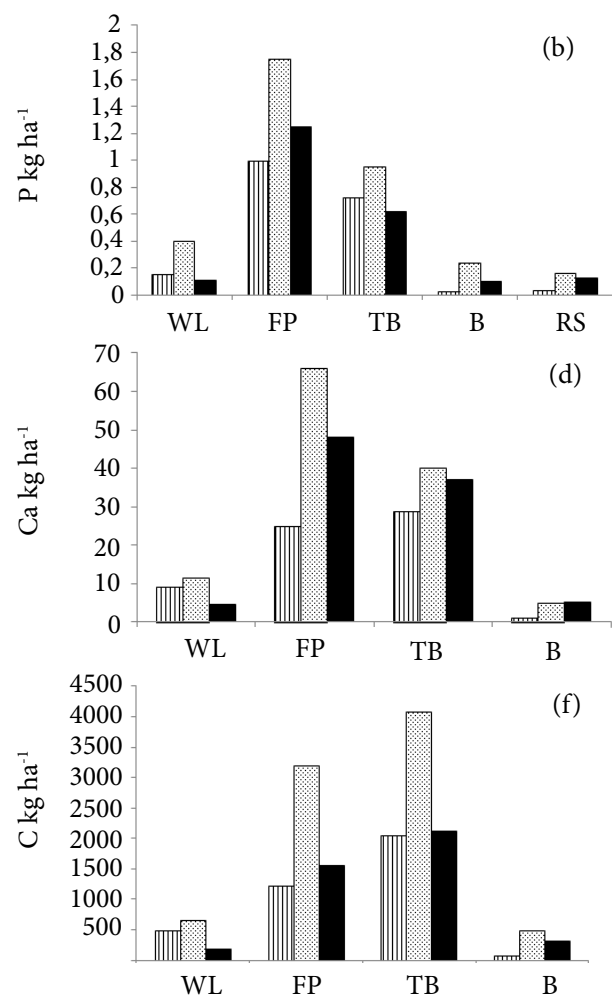
Table 3. Carbon, cellulose, lignin and polyphenols concentrations $\left(\mathrm{g} \mathrm{kg}^{-1}\right)$ in litter fractions (LF) of E. grandis stands in the first and second rotations in Northern Rio de Janeiro, Brazil.

\begin{tabular}{|c|c|c|c|c|c|c|c|c|c|c|c|c|}
\hline \multirow[t]{2}{*}{ LF } & \multicolumn{4}{|c|}{ SR2 } & \multicolumn{4}{|c|}{ R5 } & \multicolumn{4}{|c|}{ FR8 } \\
\hline & C & $\mathrm{Ce}$ & $\mathbf{L i}$ & Po & C & $\mathrm{Ce}$ & $\mathbf{L i}$ & Po & C & $\mathrm{Ce}$ & $\mathbf{L i}$ & Po \\
\hline WL & 479 & 188 & 203 & 78 & 464 & 171 & 196 & 96 & 464 & 245 & 216 & 82 \\
\hline $\mathrm{TB}$ & 425 & 284 & 324 & 10 & 439 & 250 & 362 & 26 & 424 & 266 & 420 & 23 \\
\hline $\mathrm{FP}$ & 450 & 134 & 280 & 45 & 462 & 110 & 272 & 52 & 406 & 254 & 258 & 23 \\
\hline RS & 424 & 150 & 380 & 36 & 439 & 171 & 281 & 32 & 444 & 307 & 332 & 22 \\
\hline B & 434 & 298 & 191 & 18 & 414 & 270 & 224 & 40 & 437 & 358 & 242 & 30 \\
\hline
\end{tabular}

WL: whole leaves; TB: twigs/branches; FP: fragmented pieces; RS: reproductive structures; B: bark; SR2: second rotation with 1.5 years; R5: second rotation with 5 years; FR8: first rotation; C: carbon; Ce: cellulose; Li: lignin; Po: polyphenols.

The total soluble polyphenols were present in the highest concentrations in the $\mathrm{WL}$, in comparison to the other litter constituents, in all three conditions (SR2, R5 and FR8). Among the plots, SR2 and R5 contained the lowest concentrations of this chemical component (Table 3 ). The average polyphenol concentrations, in descending order, were: $85( \pm 10.7) \mathrm{g} \mathrm{kg}^{-1}$ in WL; 40 ( \pm 17.1$) \mathrm{g} \mathrm{kg}^{-1}$ in FP; $30( \pm 8.2) \mathrm{g} \mathrm{kg}^{-1}$ in RS; 29 $( \pm 12.5) \mathrm{g} \mathrm{kg}^{-1}$ in bark; and $20( \pm 9.6) \mathrm{g} \mathrm{kg}^{-1}$ in TB. Barreto et al. (2008) reported an average concentration of $99.6 \mathrm{~g} \mathrm{~kg}^{-1}$ of polyphenols in Urograndis litter at different ages.

The litter fractions (Figure 2f) totaled $3,837 \mathrm{~kg} \mathrm{ha}^{-1}$ of C in SR2, 4,331 kg ha-1 of C in FR8 and 9,023 kg ha ${ }^{-1}$ of C in R5. The branch fraction represented the largest $\mathrm{C}$ stock in all three plots, representing $53 \%, 45 \%$ and $49 \%$ of the accumulated C in SR2, R5 and FR8, respectively. The significant carbon stock in FP is also noteworthy, representing an average of $34 \%$ of the accumulated C. Studies in Eucalyptus sp. with ages of 20, 44 and 240 months indicated carbon stocks in the litter biomass of approximately 2,170, 3,940 and 8,070 $\mathrm{kg} \mathrm{ha}^{-1}$ of C, respectively (Wink et al., 2013). In a Urograndis eucalyptus cultivation under rotation effect in China, the proportional C contribution of the litter for the total C stock of the system increased in the second rotation. This indicates an age and rotation interaction effect on the $\mathrm{C}$ accumulation in the litter (Li et al., 2015), even if, in that case, the implantation of the second rotation succeeded after burning the residue from the previous cycle. In the present study, the magnitude of the $\mathrm{C}$ accumulation effects on the plots were much higher than those reported by Li et al. (2015), most likely because of the remaining residues from the previous harvest cycle.

The litter quality is one of the factors controlling the decomposition process (Coûteaux et al., 1995). In predictive models of litter decomposition, the litter quality indices, such as $\mathrm{C} /$ nutrients, lignin concentration and lignin/nutrients ratios are widely used (Prescott, 2010). Therefore, the $\mathrm{C} / \mathrm{N}$, $\mathrm{C} / \mathrm{P}$, lignin/ $\mathrm{N}$ and lignin + cellulose $/ \mathrm{N}$ ratios of the different materials constituting the litter were estimated for the three studied conditions. It was found that the magnitude of these relations oscillated among the components (Table 4).

In the materials with the least woody tissue (WL, FP and RS), the average $\mathrm{C} / \mathrm{N}$ ratios were 46,39 and 46 , respectively. Skorupa et al. (2015) mention indices ranging from 33 to 48 in freshly fallen leaves of Urograndis hybrids of different ages, not being any significant difference among leaf litter fractions from the different sites. On the other hand, the $\mathrm{C} / \mathrm{P}$ ratio obtained in this study was substantially higher than those obtained by Skorupa et al. (2015), and the P concentration of the WL fraction (Table 2) was at least half of the one observed by these authors. Apparently, this indicates very high $\mathrm{P}$ levels in the litter, considering the limitation of this nutrient in the soil (Table 1).

The lignin/ $\mathrm{N}$ ratio was higher in the bark and branch fractions (Table 4). The 50 lignin/ $\mathrm{N}$ ratio seems to mark the separation between woody and non-woody residues (Prescott, 2005). Values from 22 to $34 \mathrm{in}$ the lignin/ $\mathrm{N}$ ratio were found in leaves of the Urograndis hybrids (Skorupa et al., 2015).

Table 4. Quality indices of the litter fractions of the E. grandis stand in the first and second rotations in Northern Rio de Janeiro, Brazil.

\begin{tabular}{cccccc} 
& \multicolumn{3}{c}{ WL } & Lig/N & lig+Cel/N \\
\hline SR2 & C/N & C/P & 22 & 42 \\
R5 & 52 & 3,193 & 16 & 29 \\
FR8 & 37 & 1,600 & 23 & 49 \\
\hline
\end{tabular}


Table 4. Continued...

\begin{tabular}{|c|c|c|c|c|}
\hline & \multicolumn{4}{|c|}{ WL } \\
\hline & $\mathbf{C} / \mathbf{N}$ & $\mathrm{C} / \mathrm{P}$ & Lig/N & $\mathrm{lig}+\mathrm{Cel} / \mathrm{N}$ \\
\hline \multicolumn{5}{|c|}{ FP } \\
\hline SR2 & 42 & 1,216 & 26 & 38 \\
\hline R5 & 41 & 3,300 & 24 & 34 \\
\hline FR8 & 34 & 1,230 & 21 & 42 \\
\hline \multicolumn{5}{|c|}{$\mathrm{TB}$} \\
\hline SR2 & 99 & 2,833 & 75 & 141 \\
\hline R5 & 102 & 4,390 & 84 & 142 \\
\hline FR8 & 92 & 3,533 & 91 & 149 \\
\hline \multicolumn{5}{|c|}{ B } \\
\hline SR2 & 94 & 3,100 & 42 & 106 \\
\hline R5 & 106 & 3,764 & 57 & 127 \\
\hline FR8 & 104 & 2,913 & 58 & 143 \\
\hline \multicolumn{5}{|c|}{ RS } \\
\hline $\mathrm{SR} 2$ & 42 & 1,034 & 38 & 53 \\
\hline R5 & 49 & 2,582 & 31 & 50 \\
\hline FR8 & 49 & 1,306 & 37 & 71 \\
\hline
\end{tabular}

WL: whole leaves; TB: twigs/branches; FP: fragmented pieces; RS: reproductive structures; B: bark; SR2: second rotation after 1.5 years; R5: second rotation after 5 years; FR8: the first rotation; C: carbon; Cel: cellulose; Lig: lignin; N: nitrogen; P: phosphorus.

The WL and the FP fractions show better quality indices, mainly due to lower $\mathrm{C} / \mathrm{N}$ and $\mathrm{L} / \mathrm{N}$ ratios. In studies involving mass loss and nutrients' mineralization in eucalyptus litter, Guo \& Sims (2002) reported the lignin/N ratios of 26 and 24, and the lignin/P ratios of 1,100 and 494, respectively, as limits above which $\mathrm{N}$ and $\mathrm{P}$ are immobilized in the decomposition process of eucalyptus litter. Thus, the higher the participation of woody residues in the litter composition, expressed by higher $\mathrm{C} / \mathrm{N}, \mathrm{C} / \mathrm{P}$ and lignin/ $\mathrm{N}$ ratios, the greater is the nutrient immobilization, as well as the retention of organic compounds rich in $\mathrm{C}$.

\section{CONCLUSION}

The amount of litter (biomass or carbon) on the soil varied according to the age of the evaluated stands, where the regrowth stands presented larger quantities of stored material than the first rotational planting at 8 years old.

The fragmented fraction, which mainly includes leaves at a partial decomposition stage, composed most of the stocked litter, thus representing higher contents of stored nutrients in the three studied conditions.

Lignin was present in higher concentrations in the woody fraction (branches), followed by the reproductive structure fraction. The fragmented leaves presented higher lignin concentration than the whole leaves, which may limit the continuity of the decomposition process at this stage.

Due to the lower values of the $\mathrm{C} / \mathrm{N}$ and $\mathrm{L} / \mathrm{N}$ quality indices, the WL and FP fractions have high recycling potential of organic matter and nutrients.

\section{SUBMISSION STATUS}

Received: 16 Mar. 2018

Accepted: 31 July 2018

Associate editor: Marcos Gervásio Pereira

(D) 0000-0002-1402-3612

\section{CORRESPONDENCE TO \\ Gláucio de Mello Cunha}

Universidade Federal do Espírito Santo (UFES), Alto Universitário, s/n, Guararema, CEP 29500-000, Alegre, ES, Brasil

e-mail: glaucio.cunha@ufes.br

\section{REFERENCES}

Amorim HB, Francelino MR, Salamene S, Pedreira LOL, Assumpção Filho LI, Capitano RC et al. Estimativa da área ocupada por reflorestamentos no estado do Rio de Janeiro. Cerne 2012; 18(1): 27-32. 10.1590/S0104-77602012000100004 
Anderson JD, Ingram JSI. Tropical soil biology and fertility: a handbook of methods. 2nd ed. Wallingford: UK CAB International; 1996. $221 \mathrm{p}$.

Barreto PAB, Gama-Rodrigues EF, Gama-Rodrigues AC, Barros NF, Fonseca S. Atividade microbiana, carbono e nitrogênio da biomassa microbiana em plantações de eucalipto, em sequência de idades. Revista Brasileira Ciência Solo 2008; 32(2): 611-619. 10.1590/S0100-06832008000200016

Bataglia OC, Furlani AMC, Teixeira JPF, Furlani PR, Gallo JR. Métodos de análise química de plantas. Boletim técnico 1983; 78.

Bremmer JM, Mulvaney CS. Nitrogen total. In: Page AL, editors. Methods of soil analysis. 2nd ed. Madison: Soil Science Society of America; 1982. p. 595-624.

Coûteaux MM, Bottner P, Berg B. Litter decomposition, climate and liter quality. Trends in Ecology \& Evolution 1995; 10(2): 63-66. 10.1016/S0169-5347(00)88978-8

Cunha GM, Gama-Rodrigues AC, Costa GS. Ciclagem de nutrientes em Eucalyptus grandis W. Hill ex Maiden no Norte Fluminense. Revista Árvore 2005; 29(3): 353-363. 10.1590/S010067622005000300002

Cunha Neto FV, Leles PSS, Pereira MG, Bellumath VGH, Alonso JM. Acúmulo e decomposição da serapilheira em quatro formações florestais. Ciência Florestal 2013; 23(3): 379-387. $10.5902 / 1980509810549$

Gatto A, Bussinguer AP, Ribeiro FC, Azevedo GB, Bueno MC, Monteiro $\mathrm{MM}$ et al. Ciclagem e balanço de nutrientes no sistema solo-planta em um plantio de Eucalyptus sp., no Distrito Federal. Revista Brasileira de Ciência do Solo 2014; 38(3): 879-887. 10.1590/ S0100-06832014000300019

Gonçalves JLM, Alvares CA, Higa AR, Silva LD, Alfenas AC, Stahl J et al. Integrating genetic and silvicultural strategies to minimize abiotic and biotic constraints in Brazilian eucalypt plantations. Forest Ecology and Management 2013; 301: 6-27. 10.1016/j.foreco.2012.12.030

Guo LB, Sims REH. Eucalypt litter decomposition and nutrient release under a short rotation forest regime and effluent irrigation treatments in New Zealand: II. internal effects. Soil Biology and Biochemistry 2002; 34(7): 913-922. 10.1016/S0038-0717(02)00023-8

Hättenschwiler S, Vitousek PM. The role of polyphenols in terrestrial ecosystem nutrient cycling. Tree 2000; 15(6): 238-243. 10.1016/ S0169-5347(00)01861-9

Laclau J, Levillain J, Deleporte P, Dieu Nzila J, Bouillet J, Saint André $\mathrm{L}$ et al. Organic residue mass at planting is an excellent predictor of tree growth in Eucalyptus plantations established on a sandy tropical soil. Forest Ecology and Management 2010; 260(12): 21482159. $10.1016 /$ j.foreco.2010.09.007

Li X, Ye D, Liang H, Zhu H, Qin L, Zhu Y et al. Effects of successive rotation regimes on carbon stocks in Eucalyptus plantations in subtropical china measured over a full rotation. Plos One 2015; 10(7): e0132558. 10.1371/journal.pone.0132858

Makkonen M, Berg MP, Handa IT, Hättenschwiler S, van Ruijven J, van Bodegom PM, Aerts R. Highly consistent effects of plant litter identity and functional traits on decomposition across a latitudinal gradient. Ecology Letters 2012; 15(9): 1033-1041. 10.1111/j.14610248.2012.01826.x

Mazid M, Khan TA, Mohammad F. Role of secondary metabolites in defense mechanisms of plants. Biology and Medicine 2011;3(2): 232-249.

Powers JS, Montgomery RA, Adair EC, Brearley FQ, DeWalt SJ, Castanho CT et al. Decomposition in tropical forests: a pan-tropical study of the effects of litter type, litter placement and mesofaunal exclusion across a precipitation gradient. Journal of Ecology 2009; 97(4): 801-811. 10.1111/j.1365-2745.2009.01515.x

Prescott CE. Litter decomposition: what controls it and how can we alter it to sequester more carbon in forest soils? Biogeochemistry 2010; 101(1): 133-149. 10.1007/s10533-010-9439-0

Rocha JHT, Gonçalves JLM, Gava JL, Godinho TO, Wichert MP. Forest residue maintenance increased the wood productivity of a Eucalyptus plantation over two short rotations. Forest Ecology and Management 2016; 379(1): 1-10. 10.1016/j.foreco.2016.07.042

Schumacher MV, Corrêa, RS, Viera M, Araújo EF. Produção de serapilheira em um povoamento de Eucalyptus urophylla $\times$ Eucalyptus globulus maidenii. Cerne 2013; 19(3): 501-508. 10.1590/ S0104-77602013000300018

Silva PHM, Poggiani F, Libardi PL, Gonçalves AN. Fertilizer management of eucalypt plantations on sandy soil in Brazil: initial growth and nutrient cycling. Forest Ecology and Management 2013; 301: 67-78. 10.1016/j.foreco.2012.10.033

Skorupa ALA, Barros NF, Neves JCL. Forest litter decomposition as affected by eucalyptus stand age and topography in south-eastern Brazil. Revista Árvore 2015; 39(6): 1055-1064. 10.1590/010067622015000600008

Souza IF, Barros NF, Silva IR, Renier RF, Ávila LS, Novais RF. Decomposition of eucalypt harvest residues as affected by management practices, climate and soil properties across southeastern Brazil. Forest Ecology and Management 2016; 374: 186-194. 10.1016/j.foreco.2016.05.012

Swift MJ, Heal OW, Anderson JM. Decomposition in terrestrial ecosystems. Vol. 5. Berkeley: University of California Press; 1979.

Turner J, Lambert MJ. Nutrient cycling in age sequences of two Eucalyptus plantation species. Forest Ecology and Management 2008; 255(5-6): 1701-1712. 10.1016/j.foreco.2007.11.038

Van Soest PJ, Wine RH. Determination of lignin and cellulose in aciddetergent fiber with permanganate. Journal of Association of Official Analytical Chemists 1968; 51(4): 780-785. 10.1093/jaoac/51.4.780

Viera M, Schumacher MV, Caldeira MVW. Dinâmica de decomposição e nutrientes em plantio de Eucalyptus Urophylla $\times$ Eucalyptus Globulus no sul do Brasil. Floresta e Ambiente 2013; 20(3): 351-360. 10.4322/floram.2013.021

Waring BG. A meta-analysis of climatic and chemical controls on leaf litter decay rates in tropical forests. Ecosystems 2012; 15(6): 999-1009. 10.1007/s10021-012-9561-Z

Wink C, Reinert DJ, Müller I, Reichert JM, Jacomet L. A idade das plantações de Eucalyptus sp. influenciando os estoques de carbono. Ciência Florestal 2013; 23(2): 333-343. 10.5902/198050989279 